\title{
Reconsidering Language Assessment Courses in Teacher Training Programs During and After the COVID-19 Pandemic
}

\begin{abstract}
Assessing learners' performance is crucial as it informs about learners' achievement levels in addition to their strengths and weaknesses, not only in face-to-face but also in online teaching. The study aimed at investigating the challenges faced by language teachers in assessing learners during online teaching and to offer some suggestions regarding language assessment courses in teacher training programs. The study adopted a qualitative approach to data collection and analysis. The participants included 22 language teachers aged between 24 to 48 . Of these teachers, 8 were male, while the rest were female. Their teaching experience varied from 2 to 25 years, with an average of 11.8 years. The data was based on the responses of the participants during semi-structured interviews. The participants were asked to attend ZOOM meetings to be held, considering their availability. The interviews lasted 10 to 25 minutes. The results of the study indicated that the challenges faced by the participants included five major themes: Assessment type, assessment item formats, support, previous training (assessment literacy), and academic integrity. Several suggestions were offered considering online testing and assessment literacy and language assessment courses in teacher training programs.
\end{abstract}

Keywords: Teacher education, ICT, curriculum development, assessment, testing

\section{Introduction}

Assessment practices in learning and teaching contexts are an indispensable part of any teaching and learning context, and language teaching is no exception since it includes gathering information on what students or learners know and how they perform based on their educational experience. Case and Obenchain (2010) stress the importance of observing and assessing students throughout the semester and informing students of their performance to focus on the weaknesses and strengths, which is also known as formative assessment. Formative assessments are planned within a face-to-face or online course or lesson and aimed at determining learner weaknesses and strengths, leading to acting accordingly through some remedial practice or tutorial. The main function of this type of assessment is that it is ongoing, consistent, and provides critical feedback to learn-

Ferit Kılıçkaya, Department of Foreign Language Education, Faculty of Education, A Block, Istiklal Campus, 15030 Burdur, ferit.kilickaya@gmail.com, http://orcid.org/0000-0002-3534-0924 
ers, while summative assessments are conducted at the end of a semester or after several weeks to measure what learners have learned (Absolum, Flockton, Hattie, Hipkins, \& Reid, 2009). This type of assessment is mainly used to indicate whether or not overall learning goals have been achieved. Formative and specifically summative assessments are mainly conducted through paper-and-pencil tests through which learners' grammar and vocabulary knowledge are assessed. Traditional assessment instruments benefiting from multiple-choice, and fill-inthe-blank are the main assessment items that focus on discrete-point assessments (Brown \& Abeywickrama, 2010; Hughes, 2003). In addition to traditional ways of assessment, teachers might also consider alternative assessment methods such as projects, self and peer assessment along with the traditional written assessment (Brumen, Cagran, \& Nixon, 2009). As Falsgraf (2009, pp. 495-496) indicates, there are several obstacles to appropriate and healthy assessment.

Most language teachers are enrolled at their department during their education on at least one course on language assessment and evaluation. One obstacle is that teachers generally may not receive the necessary training in assessment practices, leading to a lack of knowledge and practice in choosing the most appropriate instruments. Büyükkarcı (2014), in his investigation of language teachers' assessment beliefs and their practices working at primary schools in Turkey, found that although teachers have positive attitudes and beliefs about formative assessment of students' performances, they do not apply formative assessment practices. The main obstacles found to account for this are crowded/overcrowded classrooms and teachers' workload. Another similar study conducted by Han and Kaya (2014) has investigated Turkish EFL teachers' assessment preferences and practices at primary and secondary educational levels. The results show that the teachers focus more on reading and speaking skills than on listening and writing skills. Moreover, it was found that half of the teachers consider the integration of the language skills important in teaching contexts. Gender and previous training on assessment are not found to be variables that affect assessment preferences. Glover (2014) analysed the effects of examinations on teacher talk through discourse analysis. Findings suggest that teacher talk may be affected by examinations as the teachers in the study tend to move away from the role of guiding to telling in their talks. The findings also indicated that teachers feel the force to match their regular teaching with the format of the examination to better prepare students to score high on examinations. They also reported negative effects on learner motivation due to the burden and stress on the learners. Compared to the core knowledge about language testing such as types of testing, reliability, and validity, the pre-service language teachers who were the participants of the study conducted by Hatipoğlu (2010) expressed the need for more time for practising writing items for the language skills and evaluating a variety of exams conducted in various situations. 
Considering the findings of the above studies, it might be stated that teacher training programs prepare teachers, more or less, for assessments in the face-toface contexts, with no or little specific attention to online assessment practices although there might be several personal attempts to integrate technology-based assessments into the curriculum or courses. The major challenge during the pandemic was that language teachers did not have the chance to meet their students face to face in the physical classroom. Therefore, they could not move the face-toface assessment practices into online teaching environments and tried to manage by themselves, especially at the very beginning of the pandemic. This study, therefore, aimed at determining the challenges faced by language teachers regarding assessment during the pandemic and to offer some suggestions as to the content of the language assessment courses in teacher training during and after the pandemic.

\section{Material and Methods}

\subsection{Research context and participants}

The study included public high schools as the research context in Turkey. The teachers working at high schools were contacted on a Facebook group. This included around fifty thousand language teachers who were working at various schools from primary to university contexts. 22 teachers responded to the message shared on the group explaining the purpose of the study and agreed to participate in the study through semi-structured interviews. The teachers were aged between 24 to 48 . Of these teachers, 8 were male, while the rest were female. Their teaching experience varied from 2 to 25 years, with an average of 11.8 years.

\subsection{Data collection and procedure}

The study adopted a qualitative approach to the data collection process to investigate the possible answers to the research questions of the study. The data was based on the responses of the participants during the semi-structured interviews. The participants were asked to attend ZOOM meetings to be held, considering their availability. The interviews lasted 10 to 25 minutes and were not recorded as the participants did not agree. As the recording was not possible, the researcher tried to focus on the responses by taking notes. All the interviews were conducted in Turkish, and the following questions were directed to the participants: 1) How have you assessed your students during your online teaching? 2) Have you used any software or website to assess your students? 3) What has been the main purpose for assessing your students? 4) Has your school provided you with any technical or training support? In what ways? 5) Do you think that your university education has prepared you for assessing students during online teaching? In what ways? 6) What are the issues and opportunities that you have faced during your online teaching? 7) Do you have any other comments/suggestions? 


\subsection{Data analysis}

The data collected through the semi-structured interviews were subject to inductive content analysis. The notes taken from the interviews were re-read repeatedly by the researcher to determine the common themes and codes. Codes can be defined as the labels to determine recurring topics, issues, or themes in the qualitative data and to characterize particular perceptions. These themes and codes were hierarchically ranked. The emerging themes and sub-categories were checked against consistency by another expert in the field, with ample knowledge of inductive content analysis. Every effort has been made to provide compelling examples to demonstrate the themes and codes and to maintain a rich overall description; however, it can be considered quite natural to lose some depth and complexity when the analysis is to be provided in an article with strict word limitations. This is especially valid since it is difficult to provide a convincing analysis by just providing adequate examples as one or two extracts for a theme or a code.

\section{Results}

The themes and the codes, together with the exemplar responses, have been provided in Table 1. The table also includes selected quotations as a representative of the responses to the interview questions.

Table 1. Themes and codes obtained from the responses

\begin{tabular}{|c|c|c|}
\hline Themes & Codes & Examples \\
\hline \multirow{2}{*}{ Assessment type } & Formative & $\begin{array}{l}\text { "I have tried to assess my learners every two weeks or } \\
\text { so to determine the problem areas so that I can focus } \\
\text { on those issues during my online teaching in the next } \\
\text { classes". }\end{array}$ \\
\hline & Summative & $\begin{array}{l}\text { "It was almost impossible to assess my students' } \\
\text { academic achievement as the regulations did not allow } \\
\text { that". }\end{array}$ \\
\hline \multirow{2}{*}{$\begin{array}{l}\text { Assessment item } \\
\text { formats }\end{array}$} & $\begin{array}{l}\text { Traditional } \\
\text { (selected } \\
\text { response) }\end{array}$ & $\begin{array}{l}\text { "My assessment was asynchronous. I mean, I just } \\
\text { assigned assignments on EBA. My students answered } \\
\text { multiple-choice questions and matching activities to } \\
\text { review the course content". }\end{array}$ \\
\hline & $\begin{array}{l}\text { Alternative } \\
\text { assessment } \\
\text { (constructed } \\
\text { response) }\end{array}$ & $\begin{array}{l}\text { "I hardly used alternative assessments as my students } \\
\text { did not have the necessary technological devices. Some } \\
\text { used only mobile phones, while some others had laptops } \\
\text { and tablets". }\end{array}$ \\
\hline
\end{tabular}




\begin{tabular}{|c|c|c|}
\hline Themes & Codes & Examples \\
\hline \multirow[t]{2}{*}{ Support } & Technical & $\begin{array}{c}\text { "My school did not provide any technical support } \\
\text { when we had problems connecting to EBA to have } \\
\text { synchronous classes. I asked my friends or other } \\
\text { teachers to help me". }\end{array}$ \\
\hline & Training & $\begin{array}{l}\text { No training has been provided. I just watched the } \\
\text { videos shared on the school website or any other videos } \\
\text { suggested by my friends and colleagues". }\end{array}$ \\
\hline \multirow{2}{*}{$\begin{array}{l}\text { Previous training } \\
\text { (assessment literacy) }\end{array}$} & Assessing skills & $\begin{array}{l}\text { "I know how to assess the basic language skills and } \\
\text { language components though I need more practice in } \\
\text { creating and choosing appropriate assessment items". }\end{array}$ \\
\hline & $\begin{array}{c}\text { Online } \\
\text { assessment }\end{array}$ & $\begin{array}{l}\text { "I think we were not provided with detailed training and } \\
\text { practice in conducting online assessments, especially in } \\
\text { alternative assessments". }\end{array}$ \\
\hline \multirow{2}{*}{ Academic integrity } & $\begin{array}{l}\text { In-secure } \\
\text { assessment }\end{array}$ & $\begin{array}{l}\text { "Summative assessment or high-stakes exams were not } \\
\text { possible as cheating or getting others' help is easy". }\end{array}$ \\
\hline & Authorship & $\begin{array}{c}\text { "Sometimes I cannot be sure whether the work is my } \\
\text { student's work". }\end{array}$ \\
\hline
\end{tabular}

\section{Assessment type}

Regarding assessment types, although the participants did not state "formative" and "summative", the responses $(n=18)$ indicated that the participants benefited from formative assessment through multiple-choice and matching items. They benefited from several tools and websites such as Quizziz, Worldwall, and Liveworksheets both to create and to use ready-to-use materials which are created by other teachers and users. Several less frequently used assessment tools were also named, such as Kahoot and Mentimeter. However, summative assessment seemed to be a genuine concern as scoring and grading practices were determined by the Ministry of Education, and face-to-face exams were required, although it was not possible to have these exams. One of the participants expressed this in this way: "I know very well that my students also need some communicative ability in English. Although I try to integrate some listening and speaking activities in my assessment, it was not possible as attending online classes was not possible due to two main reasons. The first one was that attendance was not mandatory. Some students simply did not have the necessary equipment and access to the Internet. The assessment was often not possible, as a result" (Interviewee 12, Female).

Another participant underscored the importance of frequent testing saying that: "I believe that frequent testing and providing feedback help my students notice their weaknesses. As a result, every two weeks I give my students mini online exams including multiple-choice questions because this is the format of the test. 
But for the official examinations, I also use gap-filling exercises, especially for grammar" (Interviewee 29, Male).

\section{Assessment item formats}

Based on the responses, it was determined that the participants mainly created and used traditional (selected-response) assessment item formats such as matching, multiple-choice, and fill-in-the-blank activities. These activities were mainly assigned and conducted asynchronously. In other words, live feedback was not possible. Some $(\mathrm{n}=14)$ created activities based on gamification using websites such as Wordwall. However, the number of these activities, according to the participants, was few. Almost all the participants $(\mathrm{n}=20)$ raised serious concerns regarding alternative assessment. Considering the responses, while it is possible to say that most of the participants excelled at supplementing the lessons with authoring or using digital assessment tools, conducting alternative assessments online seemed to be impossible for the participants. Related to this, two of the participants stated that: "Each week I assign some online worksheets using the website Liveworksheets to my students. These worksheets include dialogues together with some vocabulary activities based on these dialogues. Sometimes they do their homework at home, and sometimes we check the answers during online teaching. But I could not use or, honestly speaking, do not know how to conduct an online alternative assessment" (Interviewee 8, Female). "I very well know that multiple-choice questions are just based on recognition and do not test students' productive skills. However, the tools and websites available do not allow me to create exercises requiring them to produce" (Interviewee 13, Female).

\section{Support}

A great majority of the participants $(n=17)$ indicated that the technical and training support was not sufficient, especially at the very beginning of the pandemic. They also added that they were not provided with any training regarding teaching and learning online, including assessment, except several videos that either they found themselves or that were provided to them. One participant indicated this lack of support saying that: "I felt alone when I had connection problems or needed support on how to use specific software or hardware. For example, I tried to solve my connection problems to EBA [an online platform for all teachers and students which includes online activities, exams, and tests]. We did not have any specific training on teaching or assessing skills online but attended several seminars on Facebook and YouTube" (Interviewee 7, Female). 


\section{Previous training (assessment literacy)}

Regarding training on assessment literacy during teacher training programs, most of the participants $(n=15)$ stated that they had several courses during their university education in teacher training programs on language assessment principles such as reliability and validity, writing items, and assessing skills. However, it was indicated that despite their previous training, they still felt the need to practice creating and/or choosing appropriate assessment items and scoring alternative assessment instruments. Almost all the participants $(n=21)$ pointed to the fact that they did not receive any comprehensive training on how to assess language skills and components in online or distance education environments. One participant explained this as follows: "In my opinion, I know more or less how to assess the basic language skills and language components though I need more practice in creating and choosing appropriate assessment items. I believe that we were not provided with detailed training and practice in conducting an online assessment, especially in alternative assessment" (Interviewee 5, Female).

\section{Academic integrity}

As for summative assessment and high-stakes exams through which grades are finalized, the majority of the participants raised concerns about the security of assessment and authorship. In addition to technical constraints and limitations, the participants indicated that the assessment policy required by the Ministry of National Education also kept them from utilising alternative assessments. They indicated that they had the knowledge and practice to use various alternative assessments such as assignments, projects, portfolios, and discussions. However, several concerns were voiced, such as the security of assessment, as it would not be possible to ensure that the students created the work on their own or without any unethical help or support from others. One participant indicated that: "Summative assessment or high-stakes exams were not possible as cheating or getting others' help is easy. Online quizzes cannot also be utilized as again technically it would not be possible to secure the exams. Sometimes I cannot be sure whether the work is my student's work" (Interviewee 3, Male).

\section{Discussion and conclusion}

Based on the responses, it can be stated that during the pandemic, formative assessment received more attention from the participants due to several reasons. One is that the participants were well aware that during online teaching and the pandemic, it was more crucial than ever to determine learners' strengths and weaknesses. In line with what is stressed by Folse, Hubley, and Coombe (2007), Green (2021), and Uzun and Ertok (2020), the participants highly valued formative assessment during online teaching. However, summative assessment seems to have failed during online teaching especially when it serves in the form of high-stakes exams. Therefore, 
it can be put forward that although summative assessment plays a significant role, online teaching practices lack the essential benchmark to check learners' progress, schools, and educational programmes. This might also mean that online teaching and assessment did not benefit from beneficial washback on learners (Çakır, 2017; Gastaldi \& Grimaldi, 2021; Kılıçkaya, 2016; Öztürk-Karataş \& Okan, 2019, 2021).

Regarding assessment items, it was also seen that assessing learners were limited to grammatical forms, vocabulary, and to some extent reading comprehension through selected-response items such as multiple-choice questions and matching, which is in line with findings of several other studies (Büyükkarc1, 2014; Golver, 2014; Han \& Kaya, 2014). This seems to be mainly due to the technical resources available and the features of these resources and websites such as providing immediate feedback regarding correct and incorrect answers (Ferdig, Baumgartner, Hartshorne, Kaplan-Rakowski, \& Mouza, 2020; Fitriyah \& Jannah, 2021; Paudel, 2021). The participants mainly opted for tools and websites which provide easy and free access to online assessment tools such as Quizlet and Wordwall, and Edpuzzle. This assessment practice seems to have resulted in neglecting assessment of communication and the ability to comprehend authentic materials. In addition to this, engaging in person-to-person communication in Zoom meetings and presenting topics or ideas were seldom practised by the learners during these online teaching practices.

The responses indicated that the participants received little, if not any, technical support and training when they had problems using the platform required by the Ministry of Education. The participants sought help and solutions from YouTube videos including some sort of training regarding the challenges they faced such as troubleshooting on technological devices and Internet connections, which appeared as the common challenges faced in online teaching as displayed by Canpolat and Y1ldirım (2021), and Fitriyah and Jannah (2021). This indicates that the participants lacked official support from the schools, although there were some seminars and workshops directed towards the general audience.

The participants' previous training in language assessment and evaluations prove that the participants had some experience in assessing language skills and components, such as grammar and vocabulary. However, the real challenge appeared to be related to assessing these skills online using the tools available. Most believed that they needed more practice in creating and choosing appropriate assessment items, which is consistent with findings of several other studies (Brumen et al., 2009; Hatipoğlu, 2010; Ölmezer-Öztürk, Öztürk, \& Aydın, 2021). The responses of the participants also indicated the need for training in online assessment and several websites and software to utilise online formative and summative assessment. It was made clear by the participants that individual efforts of the staff at the teacher training programmes, and the number of the courses could not be sufficient and efficient. Therefore, a carefully designed program including more 
practice and applications in assessment in both in teaching face to face and online classrooms is recommended. This could also be achieved by integrating assessment into school experience and practice teaching courses as part of the training program (Hidri, 2021).

Academic integrity was another theme that emerged during the analysis of the responses leading to two codes: insecure assessment and authorship. Considering the realities of online assessment, it might be quite natural that maintaining academic integrity would appear challenging and maybe even impossible. Implementing online exams with selected-response items is often more prone to cheating than written or spoken tasks (Harper, Bretag, \& Rundle, 2020). Most teachers, like the ones in the current study, are willing to use alternative assignments, such as reflection tasks. Several participants showed interest in take-home exams not only to benefit from the advantages of summative assessment but also to reduce students' anxiety (Bengtsson, 2019); however, they added that since they were worried about the authorship and some other technical issues; they decided not to.

In conclusion, the study tried to investigate language teachers' experience with online language assessment practices and their views regarding the challenges faced. Their responses indicated that they needed more training, practice, and support on utilizing online assessment tools, with specific needs on alternative assessment as, to some extent, they excelled at using traditional assessment items via several websites and tools available. Therefore, the results also indicated the need for reconsidering language assessment courses in teacher training programs during and after the pandemic as even when the pandemic is over and its effects are lessened, online assessment practices would be an integral part of our teaching and learning practices (Russell \& Murphy, 2021).

As with any practical research, it is worth noting that there are several limitations of the study in various aspects. It must be acknowledged that the study utilized the participants' responses in data analysis and their reported experiences were considered in data analysis, presentation of findings, and the discussion of these findings. Therefore, readers might like to take into account that what was reported by the participants might well be different from what they do or did in their teaching contexts. Therefore, further research focus on observations of online assessment practices through the example instruments as used by the participants. As a form of data triangulation, the participants could also be asked to keep a journal in which they write down their feelings and experiences on a daily basis. Furthermore, in addition to teachers' perspectives, learners' experience with online assessment and their views on academic integrity should also be investigated.

\section{Acknowledgement}

I thank the two anonymous reviewers for their helpful and constructive comments on earlier drafts of the manuscript. 
Ferit Kılıçkaya

\section{References}

Absolum, M., Flockton, L., Hattie, J., Hipkins, R., \& Reid, I. (2009). Directions for assessment in New Zealand. Retrieved April 12, 2021, from https://assessment.tki.org.nz/Research-and-readings/ Research-behind-DANZ.

Bengtsson, L. (2019). Take-home exams in higher education: A systematic review. Education Sciences, 9, 267. DOI: 10.3390/edusci9040267.

Brown, H. D., \& Abeywickrama, P. (2010). Language assessment: Principles and classroom practices (2nd ed.). New York: Pearson Education.

Brumen, M., Cagran, B., \& Rixon, S. (2009). Comparative assessment of young learners' foreign language competence in three eastern European countries. Educational Studies 35(3), 259-295. DOI: $10.1080 / 03055690802648531$.

Büyükkarc1, K. (2014). Assessment beliefs and practices of language teachers in primary education. International Journal of Instruction, 7(1), 107-120. Retrieved April 10, 2021, from http:// www.e-iji.net/dosyalar/iji_2014_1_8.pdf.

Canpolat, U., \& Yıldırım, Y. (2021). Ortaokul öğretmenlerinin COVID-19 salgın sürecinde uzaktan eğitim deneyimlerinin incelenmesi [Examining the distance education experiences of secondary school teachers in the COVID-19 outbreak process]. Açıöğretim Uygulamaları ve Araştırmaları Dergisi, 7(1), 74-109. Retrieved June 15, 2021, from https://dergipark.org.tr/en/download/article-file/1446616.

Case, R., \& Obenchain, K. M. (2010). How to assess language in the social studies classroom. The Social Studies, 97(1), 41-48. DOI: 10.3200/TSSS.97.1.41-48.

Çakır, İ. (2017). The washback effects of secondary education placement examination on teachers, school administrators and parents with specific reference to teaching English as a foreign language. Turkish Journal of Teacher Education, 6(2), 61-73. Retrieved April 12, 2021, from http:// tujted.com/makale/631.

Falsgraf, C. (2009). The ecology of assessment. Language Teaching, 42(4), 491-503. DOI: 10.1017/ S0261444808005570.

Ferdig, R. E., Baumgartner, E., Hartshorne, R., Kaplan-Rakowski, R., \& Mouza, C. (2020). Teaching, technology, and teacher education during the COVID-19 Pandemic: Stories from the field. Association for the Advancement of Computing in Education (AACE). Retrieved May 12, 2021, from https://www.learntechlib.org/p/216903/.

Fitriyah, I., \& Jannah, M. (2021). Online assessment effect in EFL classroom: An investigation on students and teachers' perceptions. Indonesian Journal of English Language Teaching and Applied Linguistics, 5(2), 265-284. Retrieved July 10, 2021 from http://www.ijeltal.org/index.php/ ijeltal/article/view/709.

Folse, K. S., Hubley, N., \& Coombe, C. (2007). A practical guide to assessing English language learners (2nd ed.). Michigan: University of Michigan Press.

Gastaldi, M. d. V., \& Grimaldi, E. (2021). COVID-19-driven sudden shift to remote teaching: the case of the Languages for the Community Program at the Universidad Nacional del Litoral. In N. Radić, A. Atabekova, M. Freddi, \& J. Schmied (Eds.), The world universities' response to COVID-19: remote online language teaching (pp. 111-124). Researchpublishing.net. DOI: 10.14705/rpnet.2021.52.1267.

Glover, P. (2014). Do language examinations influence how teachers teach? International Online Journal of Education and Teaching (IOJET),1(3), 197-214. Retrieved April 12, 2021, from http:// iojet.org/index.php/IOJET/article/view/48/67.

Green, A. (2021). Exploring language assessment and testing: Language in action (2nd ed.). London: Routledge.

Han, T., \& Kaya, H. İ. (2014). Turkish EFL teachers' assessment preferences and practices in the context of constructivist instruction. Journal of Studies in Education, 4(1), 77-93. Retrieved April 15, 2021, from http://www.macrothink.org/journal/index.php/jse/article/view/4873. 
Harper, R., Bretag, T., \& Rundle, K. (2020). Detecting contract cheating: examining the role of assessment type. Higher Education Research \& Development, 1-16. DOI: 10.1080/07294360.2020.1724899.

Hatipoğlu, Ç. (2010). Summative evaluation of an English language testing and evaluation course for future English language teachers in Turkey. English Language Teacher Education and Development (ELTED) Journal, 13, 40-51. Retrieved April 10, 2021, from http://www.elted.net/ uploads/7/3/1/6/7316005/v13_5hatipoglu.pdf.

Hidri, S. (2021). (Ed.). Perspectives on language assessment literacy: Challenges for improved student learning. London: Routledge.

Hughes, A. (2003). Testing for language teachers (2nd ed.). Cambridge: Cambridge University Press.

Kılıçkaya, F. (2016). Washback effects of a high-stakes exam on lower secondary school English teachers' practices in the classroom. Lublin Studies in Modern Languages and Literature, 40(1), 116-134. DOI: 10.17951/1smll.2016.40.1.116.

Ölmezer-Öztürk, E., Öztürk, G., \& Aydın, B. (2021). A critical evaluation of the language assessment literacy of Turkish EFL teachers: Suggestions for policy directions. In B. Lanteigne, C. Coombe, \& J. D. Brown (Eds.), Challenges in language testing around the world: Insights for language test users (pp. 411-420). Singapore: Springer Nature. DOI: 10.1007/978-981-33-4232-3.

Öztürk Karataş, T., \& Okan, Z. (2019). The power of language tests in Turkish context: A critical study. Journal of Language and Linguistic Studies, 15(1), 210-230. DOI: 10.17263/j1ls.547715.

Öztürk Karataş, T., \& Okan, Z. (2021). A conceptual framework on the power of language tests as social practice. In B. Lanteigne, C. Coombe, \& J. D. Brown (Eds.), Challenges in language testing around the world: Insights for language test users (pp. 79-98). Singapore:Springer Nature. DOI: 10.1007/978-981-33-4232-3.

Paudel, P. (2021). Online education: Benefits, challenges and strategies during and after COVID-19 in higher education. International Journal on Studies in Education, 3(2), 70-85. DOI: 10.46328/ ijonse. 32 .

Russell, V., \& Murphy-J., K. (2021). Teaching language online: A guide for designing, developing, and delivering online, blended, and flipped language courses. New York: Routledge.

Uzun, L, \& Ertok, Ş. (2020). Student Opinions on task-based approach as formative evaluation versus exam-based approach as summative evaluation in education. Sakarya University Journal of Education, 10(2), 226-250. DOI: 10.19126/suje.598048. 